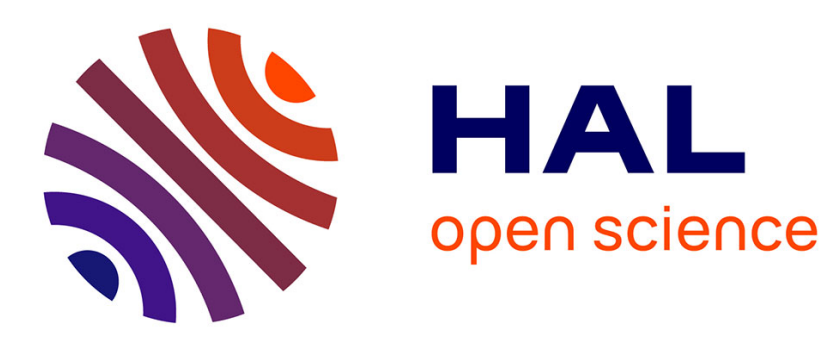

\title{
Genetic variation of chemical and mechanical traits of maritime pine (Pinus pinaster Aiton). Correlations with wood density components
}

Maria Gaspar, Alves, José Louzada, Morais, Santos, Fernandes, Maria Almeida, José Rodrigues

\section{To cite this version:}

Maria Gaspar, Alves, José Louzada, Morais, Santos, et al.. Genetic variation of chemical and mechanical traits of maritime pine (Pinus pinaster Aiton). Correlations with wood density components. Annals of Forest Science, 2011, 68 (2), pp.255-265. 10.1007/s13595-011-0034-x . hal-00930769

\section{HAL Id: hal-00930769 https://hal.science/hal-00930769}

Submitted on 1 Jan 2011

HAL is a multi-disciplinary open access archive for the deposit and dissemination of scientific research documents, whether they are published or not. The documents may come from teaching and research institutions in France or abroad, or from public or private research centers.
L'archive ouverte pluridisciplinaire HAL, est destinée au dépôt et à la diffusion de documents scientifiques de niveau recherche, publiés ou non, émanant des établissements d'enseignement et de recherche français ou étrangers, des laboratoires publics ou privés. 


\title{
Genetic variation of chemical and mechanical traits of maritime pine (Pinus pinaster Aiton). Correlations with wood density components
}

\author{
Maria J. Gaspar • Ana Alves • José L. Louzada • \\ José Morais • Antonio Santos • Claudia Fernandes • \\ Maria H. Almeida • José C. Rodrigues
}

Received: 15 February 2010 /Accepted: 21 August 2010 / Published online: 24 February 2011

(C) INRA and Springer Science+Business Media B.V. 2011

\begin{abstract}
- Background Genetic selection for one trait can have an impact on other important traits for final use; thus, it is important to assess the correlation between traits.

- Methods Genetic control and relationships among lignin content predicted by near infrared spectroscopy, radial modulus of elasticity ( $\mathrm{MOE}_{\mathrm{Rad}}$ ) and the radial modulus of rupture $\left(\mathrm{MOR}_{\mathrm{Rad}}\right)$, as well as its correlations with wood density components and spiral grain were assessed by
\end{abstract}

Handling Editor: Luc Pâques

M. J. Gaspar · C. Fernandes

Departamento Florestal,

Universidade Trás-os-Montes e Alto Douro (UTAD),

Vila Real, Portugal

\section{A. Alves $\cdot$ A. Santos $\cdot$ J. C. Rodrigues}

Centro de Florestas e Produtos Florestais,

Instituto Investigação Científica Tropical (IICT),

Tapada da Ajuda,

Lisboa, Portugal

J. L. Louzada $(\bowtie)$

Centro de Investigação e de Tecnologias

Agro-Ambientais e Biológicas, Dpto Florestal,

Universidade Trás-os-Montes e Alto Douro (UTAD),

5001-801 Vila Real, Portugal

e-mail: jlousada@utad.pt

\section{J. Morais}

Centro de Investigação e de Tecnologias

Agro-Ambientais e Biológicas, Dpto Engenharias,

Universidade Trás-os-Montes e Alto Douro (UTAD),

Vila Real, Portugal

M. J. Gaspar • M. H. Almeida

Instituto Superior de Agronomia, Centro de Estudos Florestais,

Universidade Técnica de Lisboa,

Lisboa, Portugal estimating heritability, phenotypic and genetic correlations using 552 Pinus pinaster trees from 46 half-sib families.

- Results The results of this study showed that lignin amount is under a moderate genetic control $\left(\mathrm{h}^{2}=0.34\right)$ but due to the low coefficient of variation observed, selection for lignin content through breeding could yield modest gains. Selection based on density will result in a decrease of the lignin content, and that the lignin content was more dependent on the proportion of latewood.

- Conclusions The results show that $\mathrm{MOE}_{\mathrm{Rad}}$ and $\mathrm{MOR}_{\mathrm{Rad}}$ are under moderate genetic control $\left(\mathrm{h}^{2}=0.34\right.$ and $\mathrm{h}^{2}=0.30$ respectively), suggesting possible genetic gains by selection for higher resistance and elasticity. $\mathrm{MOE}_{\mathrm{Rad}}$ had higher correlations with latewood than earlywood components. Negative correlations were observed between mechanical traits and lignin content, while the correlations with spiral grain were positive.

Keywords Heritability · Genetic correlation · Pinus pinaster . Wood quality $\cdot$ Lignin content

\section{Introduction}

Maritime pine (Pinus pinaster Ait.) is an important commercial species in southwest Europe. It is the principal conifer in Portugal, covering $710.6 \times 10^{3}$ ha, approximately $23 \%$ of the total Portuguese forestry area. The wood is remarkably versatile and it is used in both timber and pulp industries, involving different stakeholders (forest owners, the timber and pulp industries) for whom different traits may be of interest. The economic importance of this species has led to the development of genetic improvement initiatives. A national tree improvement plan has been in 
operation since the early 1980 s, with the aim of increasing volume per hectare and improving stem straightness, a well-known drawback of this species. Currently, the maritime pine breeding program has reached the second generation of selection; the progeny trial reported in this study is part of this program. The introduction of wood quality as a selection criterion is an important objective of breeding programs in order to answer the needs of industry. However, wood quality can only be defined in terms of particular end use, and may involve several traits, e.g., density, heterogeneity, chemical composition and mechanical properties (Zobel and van Buijtenen 1989). Recent maritime pine studies showed a significant genetic control of intra-ring wood density components (Louzada and Fonseca 2002; Gaspar et al. 2008a) as well as of spiral grain (Gaspar et al. 2008b).

Traditional chemical and technological tests used to assess wood traits for selection are time-consuming and destructive. These kinds of constraint are not only incompatible with tree breeding selection programs, but are also expensive.

The development of rapid, non-destructive and costeffective tools such as near infrared spectroscopy (NIR) allowed the assessment of large populations needed to provide genetic parameters estimates, in a short time at lower costs (Greaves et al. 1996; Perez et al. 2007; Raymond and Schimleck 2002). Following the introduction of these methods, the existence of genetic variation in cellulose and lignin content has been reported for different species (Hannrup et al. 2004; Perez et al. 2007; Pot et al. 2002; Ukrainetz et al. 2008). Lignin content is important for pulp production, so the correlated response in LG should be taken into consideration when deciding on a selection strategy. The chemical composition of wood can also influence the physical properties of different types of wood (Bodig 1981).

Wood mechanics are important for selection and application in various areas of engineering (Santos and Pinho 2004). Mechanical stiffness and strength of wood are combinations of its physical, chemical and anatomical properties (Steffenrem et al. 2007). Nevertheless, density is regarded as the single most important predictor of its mechanical properties (Zobel and van Buijtenen 1989), although density is not a single property, but a complex of characteristics (density components). Another key property influencing mechanical traits is spiral grain: deviation in the longitudinal orientation of the cells always reduces the longitudinal strength of wood (Zobel and van Buijtenen 1989).

Wood is an orthotropic material, with independent mechanical properties in three mutually perpendicular directions: longitudinal, radial, and tangential (Madsen 1992). Thus, for structural applications it is important to characterize not only the longitudinal mechanical properties of wood but also the properties related to its radial and tangential directions (Xavier et al. 2007). However, according to Machado and Cruz (2005) the majority of published works on the variability of mechanical properties of maritime pine have focused on the longitudinal properties. According to Ohbayashi et al. (2001), low values of modulus of rupture in the radial orientation $\left(\mathrm{MOR}_{\mathrm{Rad}}\right)$ increase the potential for within-ring internal checking. Checks occur occasionally during kiln drying of softwoods and hardwoods (Ilic 1995).

Although single trait genetic gains are possible, improvement for one trait may have consequences for others (Zobel and Talbert 1984). Sound knowledge of genetic correlations is important for both defining breeding goals and selecting the right genotypes. If improving one desired characteristic results in a reduced value for a second desirable property, a careful consideration must be made with regard to the most effective breeding plan (Zobel and van Buijtenen 1989). As most of the wood quality traits are related, it is important to evaluate the extent to which selection for density affects other wood quality parameters in maritime pine.

The aim of this study was to estimate the genetic variation of mechanical (radial modulus of rupture, radial elasticity) and chemical traits (extractives and lignin content) and the genetic and phenotypic correlation within and between these traits and intra-ring wood characteristics and spiral grain, in order to evaluate how selection for one trait affects the others. To the best of our knowledge, this is the first work where this evaluation has been performed.

\section{Materials and methods}

\subsection{Genetic material}

The progeny test used in this study belongs to a series, replicated at three sites and established in 1987. The trials included 46 open-pollinated families, originated from seed collected in the Escaroupim clonal seed orchard II. This CSO includes 49 genotypes and was established by grafting in 1975-1980, but only 46 families were considered in the progeny test due to poor seed production in the rest. The ortets were obtained from plus-trees originally selected in Mata Nacional de Leiria (lat $39^{\circ} 50^{\prime}$, long $8^{\circ} 55^{\prime}$, alt $30 \mathrm{~m}$ ) for volume, stem form, spiral grain and branch habits (Perry and Hopkins 1967).

The field trial was located at Mata Nacional de Leiria. The site is characterized by a Mediterranean climate, with a mean air temperature between $12.5^{\circ} \mathrm{C}$ and $15^{\circ} \mathrm{C}$, relative humidity between 80 and $85 \%$ and yearly rainfall between $700 \mathrm{~mm}$ and $800 \mathrm{~mm}$, with a 4-month period of summer drought. The spodic podzol (PZ sd) soils are derived from sand dunes of maritime origin. Seedlings were raised for 9 months in the nursery in $250 \mathrm{~cm}^{3}$ containers. After 
harrowing and ploughing, planting $(2 \times 2 \mathrm{~m}$ spacing) took place in March 1987 and no fertilizer was applied. The 46 families were replicated in eight blocks with $2 \times 4$ tree plots. In 2003 , wood samples were collected from a subset of 12 trees for every family in three blocks, giving a total number of 552 trees (the four trees per plot were randomly selected). In all trees, a single wood disc with a thickness of $10 \mathrm{~cm}$ was collected at a predetermined sampling height of $2 \mathrm{~m}$.

\subsection{Chemical analysis}

For chemical analysis, only the last 4 years from the bark of each disk (from 1999 to 2003) were used, in order to avoid compression wood. Samples were milled to pass $1 \mathrm{~mm}$ sieve, and aliquots of the milled wood were successively Soxhlet-extracted with dichloromethane, ethanol and water. Lignin content in percentage of extractive free oven dry weight (LG) was predicted using near infrared spectroscopy (NIR) in combination with a partial least squares regression model (PLSR) on the extractive-free wood meal samples, with OPUS Quant version 6.5 (Bruker Optics, Ettlingen, Germany) according to Perez et al. (2007). Since the PLSR model used was based on maritime pine wood samples from France, a validation of the model was performed by selecting 18 samples, from 16 different families, covering the range of estimated lignin amount (validation set). Klason lignin of the validation test set was determined according to the procedure of Schwanninger and Hinterstoisser (2002).

A Bruker Vector 22N/I spectrometer equipped with a spinning cup module was used. NIR spectra were acquired, using 100 scans per sample at $8 \mathrm{~cm}^{-1}$ spectral resolution, one spectrum per sample. Extractive-free wood powder was dried at $60^{\circ} \mathrm{C}$ overnight, and allowed to reach room temperature before spectral acquisition.

\subsection{Microsensitometric analysis}

A $2 \mathrm{~mm}$-thick radial strip segment from the pith to the bark was prepared from each disk, and then conditioned at $12 \%$ moisture content. Radial samples were X-rayed perpendicular to the transverse section, and their images scanned by microdensitometric analysis (Polge 1978). The time of exposure to radiation was $300 \mathrm{~s}$, at an intensity of $18 \mathrm{~mA}$ and an accelerating tension of $12 \mathrm{kV}$, with a $2.5 \mathrm{~m}$ distance between X-ray source and film. The data comprising the radial density profiles were recorded every $100 \mu \mathrm{m}$ with a slit height (tangential direction) of $455 \mu \mathrm{m}$.

Ring density (RD), minimum density (MND), maximum density (MXD), earlywood density (EWD), latewood density (LWD), earlywood width (EWW), latewood width (LWW), latewood percentage (LWP) and ring width (RW) were determined in each tree.
The earlywood-latewood boundary in each growth ring was assigned a fixed density of $500 \mathrm{~kg} / \mathrm{m}^{3}$ as the limit between earlywood and latewood. The advantages of this criterion for the EW/LW boundary based on a fixed density value were well explained by Jozsa et al. (1987). This value of $500 \mathrm{~kg} / \mathrm{m}^{3}$ was a result of an adjustment to the value proposed by Louzada (2000) for Pinus pinaster, where it compares different criteria and indicates that this one is the most correct for this species at 18 years old. Because rings close to the pith have less volume than those near the bark, they contribute less to the whole disc volume. To compensate for this effect, wood density components were weighed for each ring by its respective cross-sectional area. These area-weighed cumulated traits are henceforth referred to simple as cumulated traits or values.

\subsection{Mechanical analysis}

The same strips were used to evaluate $\mathrm{MOE}_{\mathrm{Rad}}$ and $\mathrm{MOR}_{\mathrm{Rad}}$, through three-point bending tests (Brancheriau et al. 2002). Before testing, the specimen dimensions (thickness and width) were measured with a digital calliper (0.01 mm resolution). Bending tests were carried out at room temperature with an electro-mechanical testing machine (Instron 5848 MicroTester ${ }^{\mathbb{R}}$ ) with a $0.5 \mathrm{~mm} / \mathrm{min}$ displacement control and $40 \mathrm{~mm}$ span.

Spiral grain (SPG) was measured at the most recently formed latewood of the last ring, using a grain slope detector and the pith as a reference as described by Gaspar et al. (2008b). Spirality direction was indicated by assigning a positive sign to the left-handed angles. Measurements in each disc were taken in two opposite radii, and the mean grain angle was calculated as the mean of the absolute value of the angles, ignoring differences in sign.

\subsection{Data analysis}

The mixed linear model associated with the data for a given trait was:

$\mathrm{Y}_{\mathrm{ijk}}=\mu+\mathrm{B}_{\mathrm{j}}+\mathrm{F}_{\mathrm{i}}+\mathrm{B} \times \mathrm{F}_{\mathrm{ij}}+\varepsilon_{\mathrm{ijk}}$

where $\mathrm{Y}$ represents the phenotypic individual observation, $\mu$ is the overall mean, $B_{j}$ is the effect of the ${ }^{{ }^{\text {th }}}$ block (fixed), $F_{i}$ is the effect of the $i^{\text {th }}$ family (random), $B \times F_{i j}$ is the effect of the interaction between the $i^{\text {th }}$ family and the $j^{\text {th }}$ block (random), and $\varepsilon$ is the residual error. Variance components for family $\left(\sigma_{\mathrm{f}}^{2}\right)$, family-block interaction $\left(\sigma_{\mathrm{f} \times \mathrm{b}}^{2}\right)$ and residual errors $\left(\sigma_{\varepsilon}^{2}\right)$, with the respective associated standard errors, were estimated by restricted maximum likelihood, using the average information REML algorithm implemented in the ASREML programme (Gilmour et al. 1998). 
Narrow sense heritability $\left(\mathrm{h}_{\mathrm{i}}^{2}\right)$ was calculated for each trait measured as:

$\mathrm{h}_{\mathrm{i}}^{2}=\frac{\sigma_{\mathrm{a}}^{2}}{\sigma_{\mathrm{P}}^{2}}$

where $\sigma_{\mathrm{a}}^{2}$ represents the additive genetic variance and $\sigma_{\mathrm{P}}^{2}$ the total phenotypic variance. Total phenotypic variance was estimated as:

$\sigma_{\mathrm{P}}^{2}=\sigma_{\mathrm{f}}^{2}+\sigma_{\mathrm{f} \times \mathrm{b}}^{2}+\sigma_{\varepsilon}^{2}$.

and adjusted additive variances as:

$\sigma_{\mathrm{a}}^{2}=\frac{1}{0.26} \times \sigma_{f}^{2}$

where the coancestry coefficient $(0.26)$ was obtained from correlated paternity, estimated by molecular markers (Gaspar et al. 2009). Standard errors for heritability were estimated by ASREML using a Taylor series approximation (Gilmour et al. 1998).

The genetic and phenotypic correlations between all wood traits were calculated using a multivariate extension of model (1). When the family effect was found to be null for any of the traits analysed in the univariate analysis, this effect was not included in the multivariate analysis. Genetic correlations between traits ( $X$ and $Y$ ) were evaluated as follows:

$r_{a}=\frac{\operatorname{cov}_{a}(x, y)}{\sqrt{\sigma_{a x}^{2} \cdot \sigma_{a y}^{2}}}$

where $\operatorname{cov}_{a}(\mathrm{x}, \mathrm{y})$ is the additive genetic covariance, and $\sigma_{a x}^{2}$ and $\sigma_{a y}^{2}$ are the additive variance components for traits $\mathrm{X}$ and $\mathrm{Y}$ respectively.

The phenotypic correlation between traits ( $\mathrm{X}$ and $\mathrm{Y}$ ), was estimated as:

$r_{p}=\frac{\operatorname{cov}_{P}(x, y)}{\sqrt{\sigma_{P x}^{2} \cdot \sigma_{P y}^{2}}}$

where $\operatorname{cov}_{P}(x, y)$ is the phenotypic covariance between traits $\mathrm{X}$ and $\mathrm{Y}, \sigma_{P x}^{2}$ and $\sigma_{P y}^{2}$ are the phenotypic variances for traits $\mathrm{X}$ and $\mathrm{Y}$ respectively. Standard errors for genetic and phenotypic correlations were estimated by ASREML, a Taylor series approximation (Gilmour et al. 1998).

Selection for one trait $\mathrm{x}$ will result in a correlated response of other traits, and the correlated response of a trait y can be estimated by using the equation of indirect response (Falconer and Mackay 1996).

$\mathrm{Cr}_{\mathrm{y} / \mathrm{x}}=\mathrm{i} \cdot \mathrm{h}_{\mathrm{x}} \cdot \mathrm{h}_{\mathrm{y}} \cdot \mathrm{r}_{\mathrm{g}(\mathrm{xy})} \cdot \sigma_{\mathrm{Py}}$

\section{Results and discussion}

\subsection{Extractives}

The total extractives content (TE) was $4.2 \%$, and water extractives were the main contributor for the total extractives amount, with an average of $1.8 \%$, followed by dichloromethane $1.6 \%$ and ethanol $1.2 \%$. Variation between trees within families was larger than the variation between families for all solvents. It is particularly evident that dichloromethane showed the larger variation both among and between families, with a range from traces to $9.2 \%$ (Fig. 1). However, the standard deviation was only 0.9 due to the fact that only a few samples (7), probably with resin, show a dichloromethane content above 3\%. This may explain the lack of variation between families (Table 1), even when samples with higher extractives content were discarded, suspected of having resin. Perez et al. (2007) reported a significant variation at the family level for a trial in France, with similar results: total extractives $4.8 \%$, dichloromethane $1.6 \%$, ethanol $1.2 \%$, and water $2.0 \%$.

Table 1 gives descriptive statistics and respective heritability estimation for each characteristic.

\subsection{Lignin}

The selected samples (validation set) used to validate the PLSR model had an estimated lignin content ranging from 26.4 to $32.0 \%$, with an average of $28.8 \%$ and a standard deviation of $1.64 \%$, according to the PLSR model. The Klason lignin determination of the same set ranged from 26.7 to 31.8 , with an average of $28.9 \%$. A coefficient of determination $\left(\mathrm{R}^{2}\right)$ of 0.95 was obtained with a root mean square error of prediction (RMSEP) of 0.38 , a residual prediction deviation (RPD) of 4.3 and -0.04 biases. The RPD value of about 4 fully catches the requirements of AACC Method 39-00 AACC-Standards 2001 for screening in breeding programs $(\mathrm{RPD} \geq 2.5)$, and is close to the requirement for quality control $(\mathrm{RPD} \geq 5$ ).

Average lignin content (LG) was $28 \%$, with a coefficient of variation $(\mathrm{CV})$ of $3 \%$. Mean LG values were within the expected range [25\%-31\%] for the same species on different sites in France (Alves et al. 2006; Perez et al. 2007; Pot et al. 2006). Nevertheless, differences between harvest age and the possible contribution of compression wood should be taken into consideration when comparing data from different sources. Variation in the percentage of lignin is associated with the existence of reaction wood (compression wood in softwoods). Compression wood contains more lignin and less cellulose than normal wood (Tsoumis 1991). Therefore, the existence of this kind of wood may influence lignin content. In our case, CW was carefully avoided (Fig. 2). 
Fig. 1 Within and between family variations of dichloromethane extractives. The within family variation is always much larger

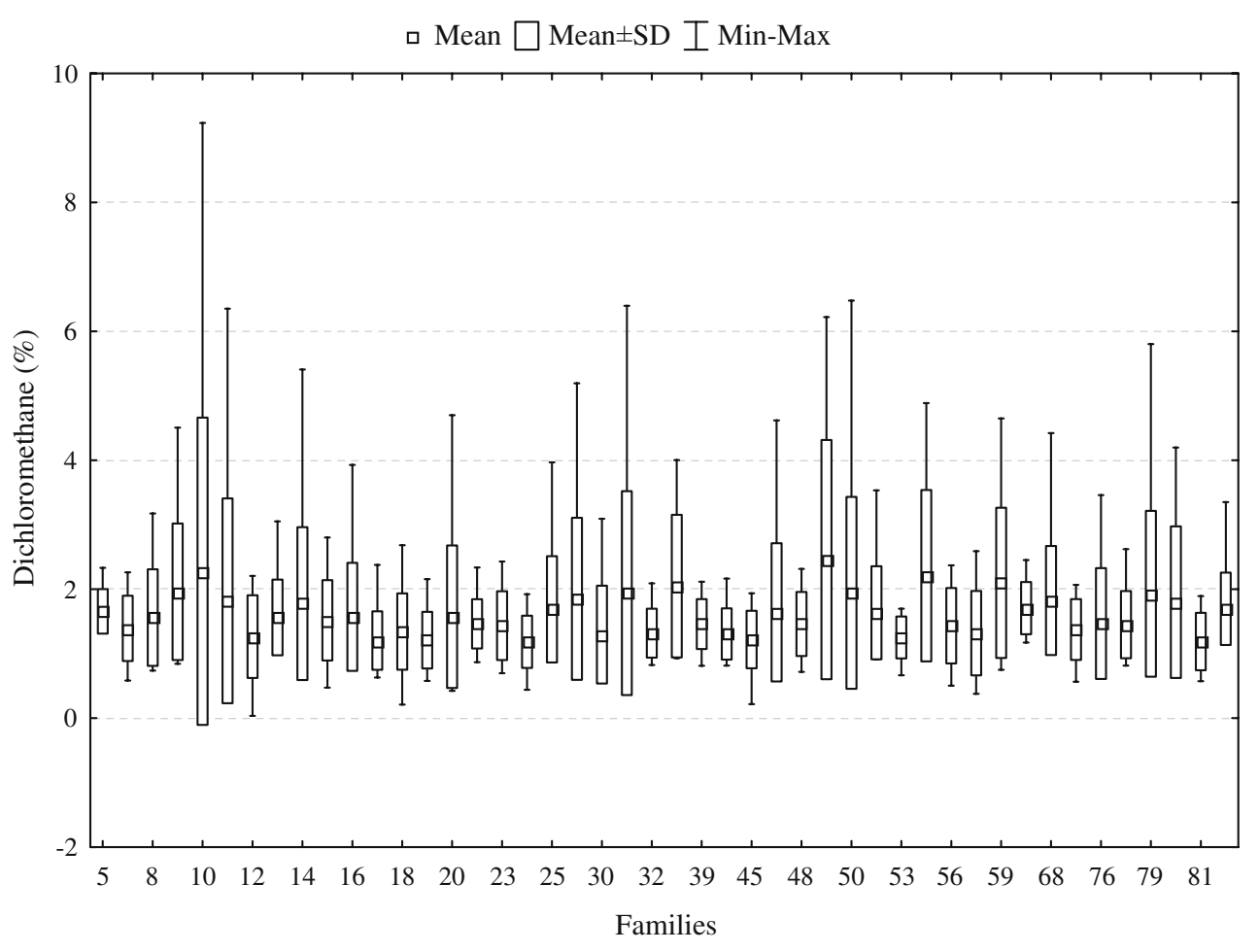

Highly significant $(p<0.001)$ differences between families were observed for this trait. The heritability value estimated $\left(\mathrm{h}_{\mathrm{i}}^{2}=0.34\right)$, suggests that lignin amount is under a moderate genetic control. This value is lower than the one reported by Pot et al. (2002) $\left(\mathrm{h}_{\mathrm{i}}^{2}=0.47\right)$ in 15 -year-old trees of the same species in France, using FTIR. Even higher heritability estimates for this trait $\left(h_{i}^{2}=0.75\right)$ were reported by Perez et al. (2007), also in France, in a 14-yearold trial of the same species, with lignin content estimated by the same NIR-PLSR model used in the present work. In a study performed in Pinus taeda, using microanalytical techniques, Sykes et al. (2006) encountered an individual- tree heritability estimative of 0.12 and 0.23 . In contrast, Ukrainetz et al. (2008) did not find significant statistical differences between families of Pseudotsuga menziesii, for this trait, using a microanalytical technique. Different heritability estimates may result from the different environmental conditions, as heritability of a particular trait can vary with the population, age, and test location.

Hannrup et al. (2004), assessing lignin content by FTIR spectroscopy for Picea abies, obtained a lower narrow sense heritability value $\left(h_{i}^{2}=0.10\right)$, but a higher broad sense heritability $\left(\mathrm{H}^{2}=0.54\right)$. According to these authors, non-additive effects may contribute to the high broad-sense

Table 1 Descriptive statistics for chemical (lignin and extractives amount) and mechanical traits (MOR Rad $\left._{\text {and }} \mathrm{MOE}_{\mathrm{Rad}}\right)$ and the corresponding heritability $\left(\mathrm{h}^{2}\right)$ at individual (tree) and family level

\begin{tabular}{|c|c|c|c|c|c|c|c|c|c|c|}
\hline \multirow[t]{2}{*}{ Trait } & & \multirow[t]{2}{*}{ Mean } & \multicolumn{4}{|c|}{ Individual level } & \multicolumn{3}{|c|}{ Family level } & \multirow[t]{2}{*}{$h^{2}$} \\
\hline & & & SD & Max & Min & $\mathrm{CV}$ & Max & Min & $\mathrm{CV}$ & \\
\hline LG (\%) & & 28.1 & 0.8 & 32 & 26.4 & 2.9 & 29.0 & 27.6 & 1.2 & $0.34 \pm 0.147$ \\
\hline \multirow[t]{4}{*}{ Extractives content } & Dichlorometane (\%) & 1.6 & 0.9 & 9.2 & 0.0 & 58.9 & 2.5 & 0.19 & 19.6 & $\mathrm{a}$ \\
\hline & Ethanol (\%) & 1.2 & 0.4 & 3.5 & 0.1 & 32.2 & 1.7 & 0.13 & 13.4 & $\mathrm{a}$ \\
\hline & Water $(\%)$ & 1.8 & 0.2 & 3.1 & 1.3 & 13.3 & 2.0 & 0.05 & 4.6 & $\mathrm{a}$ \\
\hline & Total \%) & 4.2 & 2.1 & 21.0 & 1.5 & 48.8 & 6.0 & 3.12 & 16.7 & $\mathrm{a}$ \\
\hline $\mathrm{MOR}_{\mathrm{Rad}}(\mathrm{MPa})$ & & 13.7 & 1.7 & 19.8 & 8.8 & 12.5 & 16.1 & 12.3 & 5.3 & $0.34 \pm 0.131$ \\
\hline $\mathrm{MOE}_{\mathrm{Rad}}(\mathrm{GPa})$ & & 1.1 & 0.1 & 1.72 & 0.8 & 13.2 & 1.3 & 1.0 & 5.5 & $0.30 \pm 0.143$ \\
\hline
\end{tabular}

a: the differences between families were not significant $(P>0.05) . \mathrm{LG}=$ lignin content in percentage of extractive free oven dry weight; $\mathrm{MOR}_{\mathrm{Rad}}$

$=$ radial modulus of rupture, $\mathrm{MOE}_{\mathrm{Rad}}=$ radial elasticity module 
Fig. 2 Between and within family variation of lignin content. The range of variation between families is less than $1.5 \%$ from 27.5 to $29 \%$, whereas most families had ranges about two times higher; as an extreme example family 25 ranges from about 27 to 32

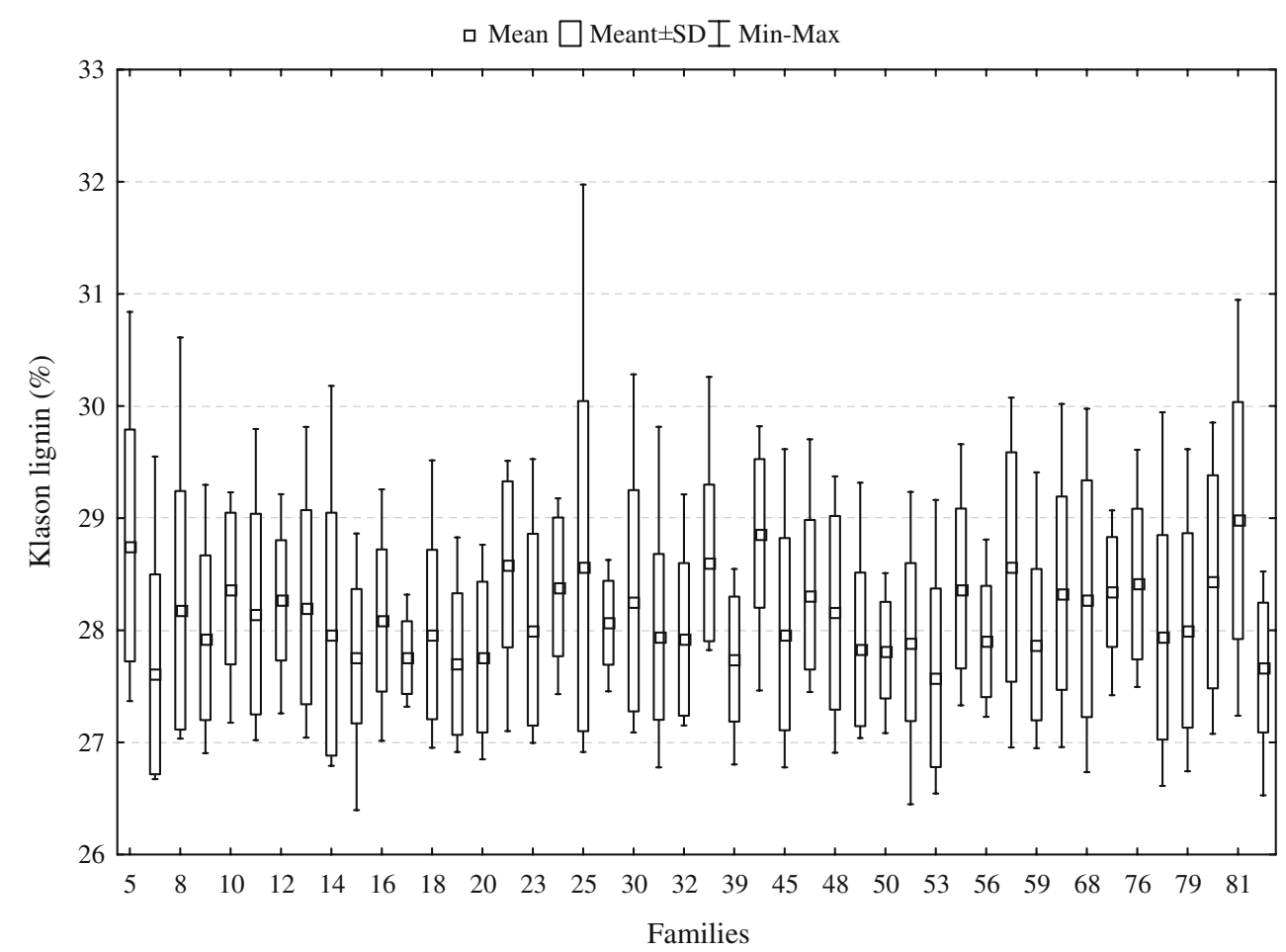

heritabilities for lignin content. However, Pot et al. (2002) only detected additive genetic effects for lignin content in Pinus pinaster.

\subsection{Mechanical traits}

As far as mechanical traits are concerned, the mean value obtained for $\mathrm{MOR}_{\mathrm{Rad}}$ and $\mathrm{MOE}_{\mathrm{Rad}}$ was $13.7 \mathrm{MPa}$ and 1.1 GPa respectively, with a CV of approximately $13 \%$ for both traits. Ohbayashi et al. (2001) reported a lower $\mathrm{MOR}_{\mathrm{Rad}}$ for radiate pine $(7.8 \mathrm{MPa})$.

Figure 3 show graphs of family mean values for mechanical traits.

Family 32 had the highest mean values for both traits $\left(\mathrm{MOE}_{\mathrm{Rad}}=1.3 \mathrm{GPa}, \mathrm{MOR}_{\mathrm{Rad}}=16.1 \mathrm{MPa}\right)$ while minimum values obtained for $\mathrm{MOE}_{\text {Rad }}$ and $\mathrm{MOR}_{\text {Rad }}$ were $1.0 \mathrm{GPa}$ and $12.3 \mathrm{MPa}$ for families 78 and 30 respectively.

$\mathrm{MOR}_{\mathrm{Rad}}$ and $\mathrm{MOE}_{\mathrm{Rad}}$ had moderate heritability values of $0.34 \pm 0.131$ and $0.30 \pm 0.143$ respectively, indicating that in maritime pine, these traits are subjected to a modest genetic control. The genetic control of mechanical properties is not as well-documented as that of growth characteristics or wood density. No other studies evaluating the genetic control of mechanical traits on radial direction can be found in the literature. Nevertheless, the estimated heritabilities for this trait corresponded well with results found in previous studies performed in other coniferous species, for longitudinal MOE and MOR (Fujimoto et al. 2006; Kumar et al. 2006), and also with other works where Silviscan technology was used (Baltunis et al. 2007) and with MOE measured acoustically (Matheson et al. 2008). Differences between families with highest and lowest $\mathrm{MOE}_{\mathrm{Rad}}$ and $\mathrm{MOR}_{\mathrm{Rad}}$, allied with the values of heritability estimates, indicate that selection for higher radial resistance and radial elasticity through breeding could yield some genetic gains.

\subsection{Genetic correlations between traits}

Phenotypic and genetic correlations observed between LG, $\mathrm{MOR}_{\mathrm{Rad}}$ and $\mathrm{MOE}_{\mathrm{Rad}}$ and the other traits are presented in Tables 2 and 3. LG presented low or even no phenotypic and genetic correlation values for most of the characteristics assessed. Phenotypic correlations were negative, with the exception of growth traits (i.e., EWW and LWW) where moderate-low positive correlations were detected. Latewood density components (MXD and LWD) had low but negative correlations. The strongest genetic correlations observed were moderately negative and were found in LWP and LWW $\left(r_{\mathrm{g}}=-0.225 ; r_{\mathrm{g}}=-0.313\right)$. Correlations with RD (Fig. 4) were also negative but low ( -0.157$)$, suggesting that selection based on wood density will result in a decrease of LG.

Previous studies carried out with $P$. pinaster (Pot et al. 2002), Picea abies (Hannrup et al. 2004) and Pseudotsuga menziesii (Chantre et al. 2002) indicated the existence of strong negative genetic correlations between these two traits. Correlations between RD and lignin content have important industrial implications, since selection for increased density will increase pulp yield per hectare and 
Fig. 3 Between and within family variation for radial strength $\left(\mathrm{MOR}_{\mathrm{Rad}}\right)$ and radial modulus of elasticity (MOE $\left.\mathrm{Rad}_{\text {ad }}\right)$
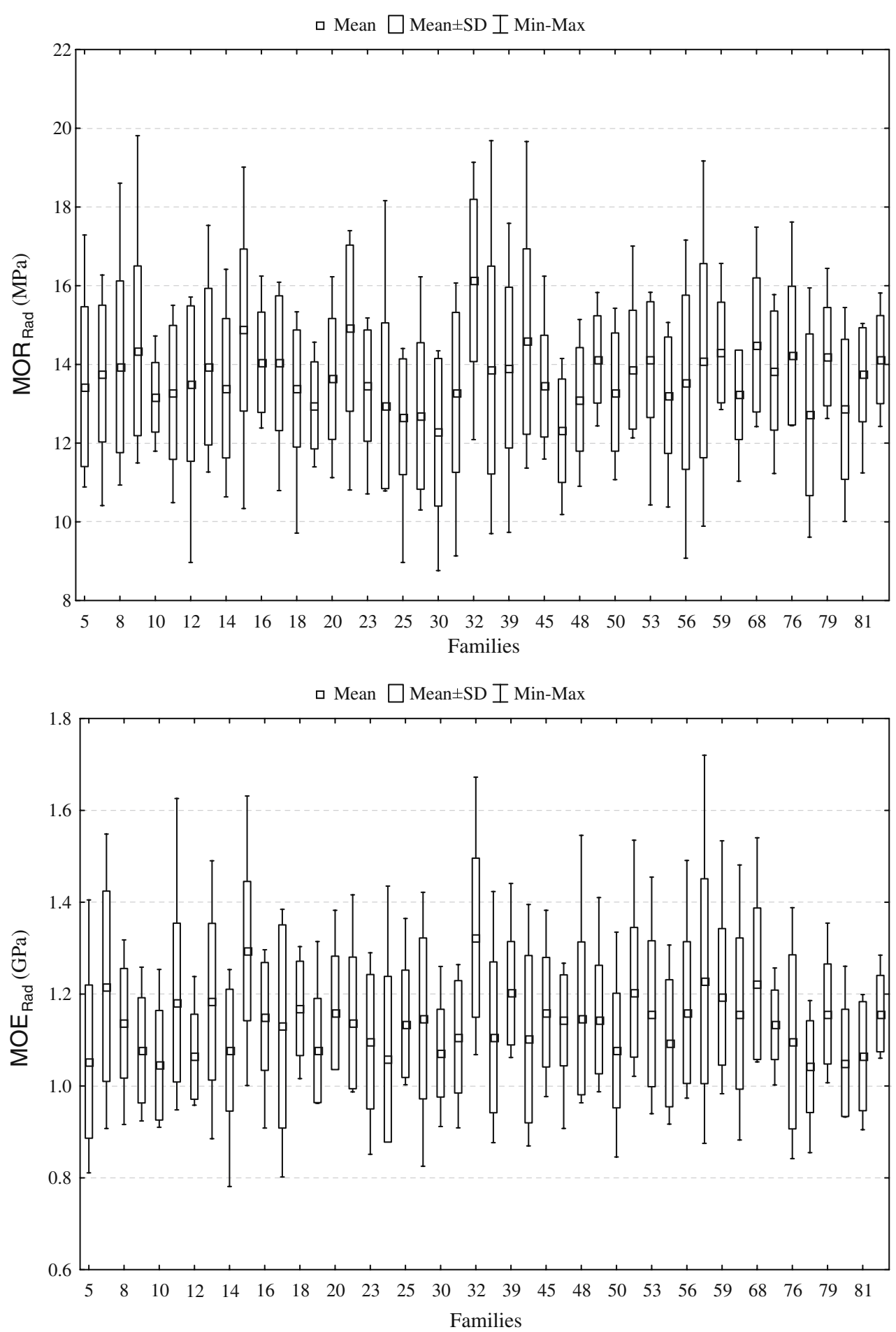

decrease production costs. Perez et al. (1995) in a work performed with $P$. pinaster obtained negative correlations between pulp yield and lignin content, and a positive correlation between pulp yield and cellulose content. Our results also showed that lignin content was more dependent on the proportion of latewood present on the ring (LWP and LWW). These results suggest that increasing the existence of latewood would decrease the lignin content. Similar findings were obtained by Hannrup et al. (2004) where a negative genetic correlation between LWP and lignin content $\left(r_{\mathrm{g}}=-0.49\right)$ was found. Sykes et al. (2006) concluded that latewood within a growth ring of loblolly pine had more desirable wood properties than earlywood, since cellulose content was higher and lignin content lower in latewood. In fact, results of a previous study performed with the same samples (Gaspar et al. 2008b) showed that 

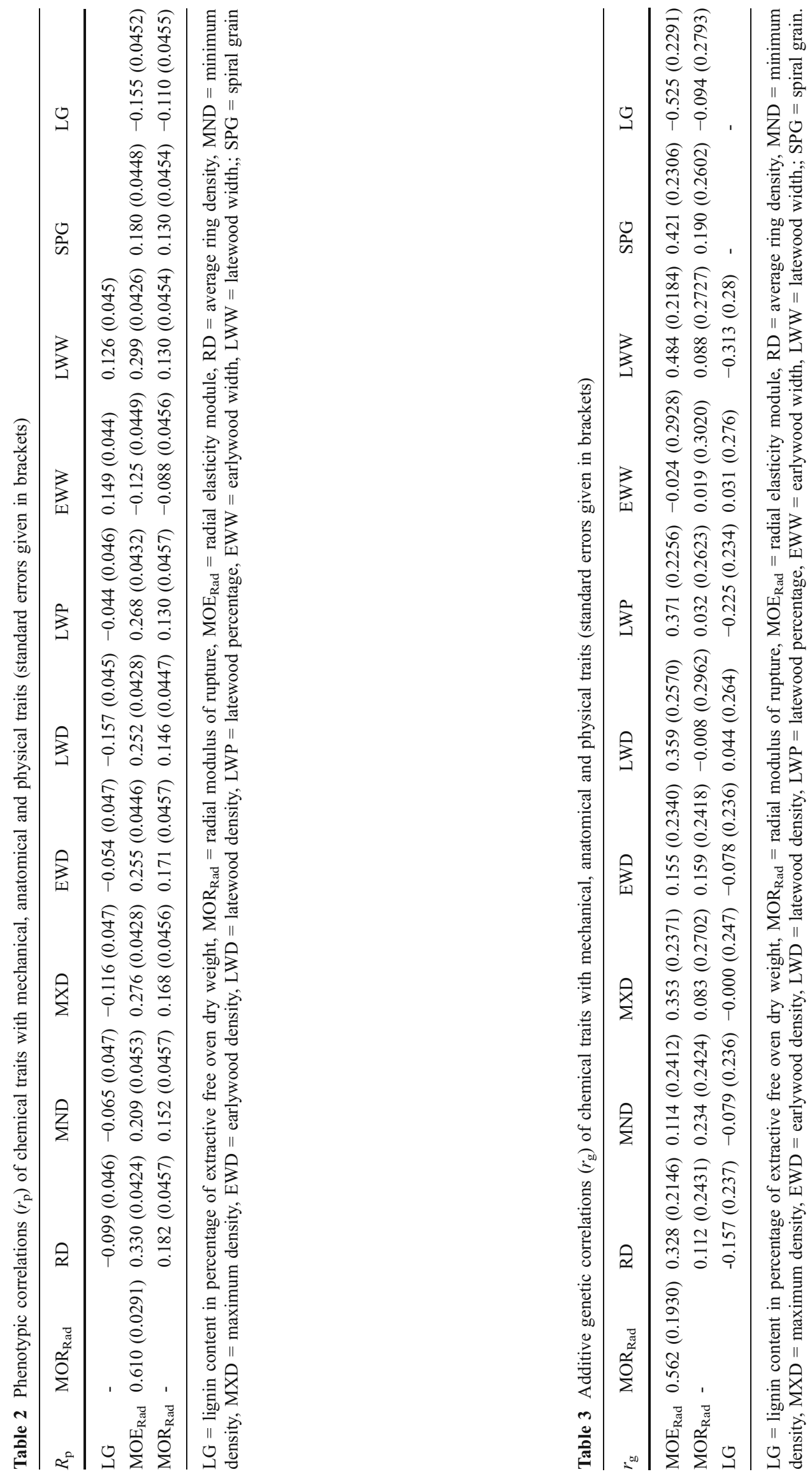


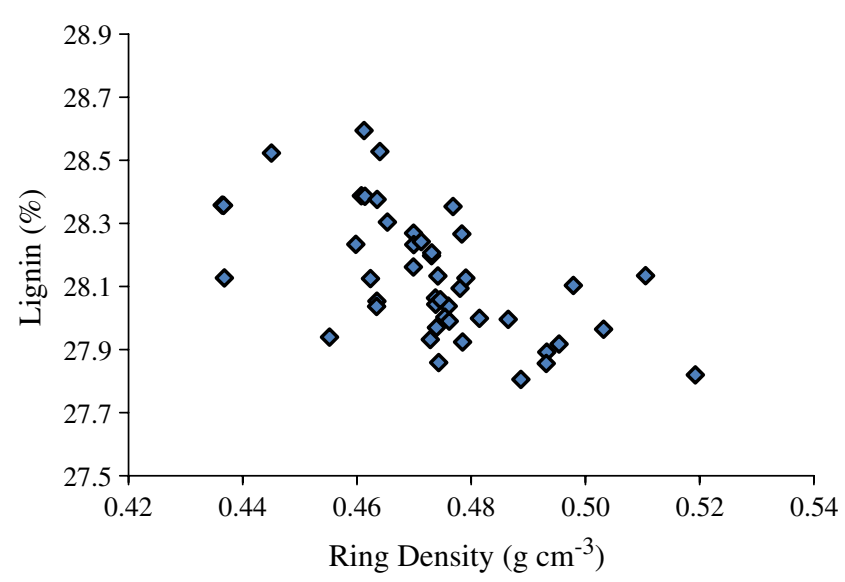

Fig. 4 Plot of the relationship between family breeding values for ring density and lignin content

$\mathrm{RD}$ is genetically highly positively correlated with LWW $\left(r_{\mathrm{g}}=0.99\right)$ and negatively with EWW $\left(r_{\mathrm{g}}=0.85\right)$. Thus, it is to be expected that LG also presents higher negative correlations with latewood intra-ring traits, and positive ones with EWW, by virtue of having a negative genetic correlation with RD. Results from a previous study also showed that selection for higher density could be performed by increasing either LWP or EWD (Gaspar et al. 2008a). Additionally, as stated above, results showed a negative genetic correlation between lignin content and the proportion of latewood present on the ring $\left(r_{\mathrm{g}}=-0.23\right)$, and an almost null correlation with EWD $\left(r_{\mathrm{g}}=-0.08\right)$ was obtained in the current work.

The two mechanical traits showed a high phenotypic and genetic correlation between each other $\left(r_{\mathrm{g}}=0.61\right.$ and $r_{\mathrm{g}}=$ 0.56 respectively). These results indicate that these traits are, at least to a large extent, controlled by the same set of genes, and that indirect selection procedures could be carried out on these characteristics. Both mechanical traits presented positive phenotypic or genetic correlations with $\mathrm{RD}$. These findings are consistent with those previously obtained (Hannrup et al. 2004; Steffenrem et al. 2007), although the mechanical traits were not evaluated in the radial direction.

Our findings also indicate that $\mathrm{MOE}_{\mathrm{Rad}}$ was genetically more dependent on latewood components, both density (MXD and LWD) and growth ones (LWP and LWW). The highest positive genetic correlation observed in this work was between $\mathrm{MOE}_{\text {Rad }}$ and LWW, indicating that selection for high latewood percentage would increase wood stiffness. As $\mathrm{MOE}_{\mathrm{Rad}}$ had a high genetic correlation with RD, it would be expected that $\mathrm{MOE}_{\mathrm{Rad}}$ also presented high positive correlations with latewood intra-ring traits, and negative ones with EWW. These findings are in agreement with the "weak band theory" proposed by Bodig (1965) and Kennedy (1967) cited by Liu and Ross (2005). According to these authors, in the radial direction earlywood and latewood bands are arranged in series, perpendicular to the applied load. Under the same load, latewood deforms less than earlywood. Failure occurs first in the weakest earlywood band, subsequent failures occur in other earlywood bands and then in latewood bands as compression progresses. Thus, improvement for high earlywood density will increase the loading capacity in the radial direction. With the exception of MND and EWD, lower correlations of $\mathrm{MOR}_{\mathrm{Rad}}$ with all the intra-ring traits were obtained. These results suggest that $\mathrm{MOR}_{\text {Rad }}$ could be enhanced through the improvement of earlywood density, even though this trait is less affected by intra-ring variations than $\mathrm{MOE}_{\text {Rad }}$.

Phenotypic and genetic correlations of mechanical traits with SPG were positive but low, with the exception of the moderate genetic correlation with $\mathrm{MOE}_{\mathrm{Rad}}\left(r_{\mathrm{g}}=0.421\right)$. A negative relation between $\mathrm{MOE}_{\text {Rad }}$, measured in the longitudinal direction, and spiral grain or microfibril angle was reported by Hannrup et al. (2004). One possible explanation for our results may be the genetic correlation observed between SPG and RD $\left(r_{\mathrm{g}}=0.55\right)$ and LWW $\left(r_{\mathrm{g}}=\right.$ 0.51) in the same samples (Gaspar et al. 2008b), since $\mathrm{MOE}_{\text {Rad }}$ also presented positive genetic correlations with RD and LWW (0.33 and 0.48 respectively). Spiral grain does not have an overwhelming influence on mechanical performance in the radial direction, so it is possible that the correlation between SPG and $\mathrm{MOE}_{\mathrm{Rad}}$ is a result of an indirect relation with other traits. Thus, it is expected that the tendency of $\mathrm{MOE}_{\mathrm{Rad}}$ to increase with SPG is a consequence of a higher incidence of juvenile wood and/

Table 4 Expected correlated responses at $10 \%$ selection intensity for each trait considering selection for chemical (LG) and mechanical traits $\left(\mathrm{MOE}_{\mathrm{Rad}}\right.$ and $\left.\mathrm{MOR}_{\mathrm{Rad}}\right)$. Genetic gain in trait units $(\mathrm{GG})$ and in percent $(\mathrm{GG} \%)$

\begin{tabular}{|c|c|c|c|c|c|c|}
\hline & \multicolumn{2}{|l|}{ LG } & \multicolumn{2}{|c|}{$\mathrm{MOE}_{\mathrm{Rad}}$} & \multicolumn{2}{|c|}{$\mathrm{MOR}_{\mathrm{Rad}}$} \\
\hline & GG & $\mathrm{GG} \%$ & GG & GG $\%$ & GG & GG\% \\
\hline $\mathrm{RD}$ & 0.37 & -22.06 & 0.51 & 7.72 & 0.63 & 32.69 \\
\hline EWD & 0.34 & -13.12 & 0.40 & 4.37 & 0.60 & 55.54 \\
\hline LWD & 0.64 & 3.04 & 0.64 & 4.16 & 0.61 & -1.15 \\
\hline LWP & 37.89 & -0.34 & 38.05 & 0.09 & 38.05 & 0.10 \\
\hline DBH12 & 10.17 & -1.05 & 10.29 & 0.09 & 10.18 & -0.99 \\
\hline HT12 & 6.69 & -2.97 & 6.92 & 0.34 & 6.79 & -1.62 \\
\hline DBH17 & 13.13 & -1.00 & 13.28 & 0.12 & 13.25 & -0.10 \\
\hline MOE & 0.89 & -21.32 & - & - & - & - \\
\hline MOR & 13.67 & -0.11 & - & - & - & - \\
\hline SPG & - & - & 4.25 & 0.96 & 10.29 & 0.09 \\
\hline LG & - & - & 28.09 & -0.15 & 4.44 & 5.38 \\
\hline
\end{tabular}

$\mathrm{LG}=$ lignin content in percentage of extractive free oven dry weight.; $\mathrm{MOR}_{\mathrm{Rad}}=$ radial modulus of rupture, $\mathrm{MOE}_{\mathrm{Rad}}=$ radial elasticity module, $\mathrm{RD}=$ average ring density, $\mathrm{EWD}=$ earlywood density, $\mathrm{LWD}=$ latewood density, LWP = latewood percentage, DBH12 - breast height diameter at 12 years old, HT12 -total height at 12 years old, DBH17 breast height diameter at 17 years old, $\mathrm{SPG}=$ spiral grain. 
or presence of reaction wood, which confounds the relation between these traits. For example, it is probable that a tree with a high incidence of reaction wood presents higher values of SPG (Harris 1989); since reaction wood in softwoods is characterized by high values of LWP, LWW and RD (Zobel and van Buijtenen 1989), high MOE $\mathrm{Rad}_{\mathrm{R}}$ values are to be expected. Therefore, it is possible that SPG is positively correlated with $\mathrm{MOE}_{\mathrm{Rad}}$, due to the indirect effect of reaction wood.

Phenotypic correlations between mechanical traits and LG were weak and negative $\left(r_{\mathrm{g}(\mathrm{MOE})}=-0.155\right.$ and $\left.r_{\mathrm{g}(\mathrm{MOR})}=-0.110\right)$. The genetic correlation obtained between $\mathrm{MOE}_{\mathrm{Rad}}$ and LG was also negative but considerably higher $(-0.525)$, while the correlation with $\mathrm{MOR}_{\mathrm{Rad}}$ was also negative but very weak (-0.094). Similar genetic correlations between these traits have been obtained by others (Chantre et al. 2002; Hannrup et al. 2004; Steffenrem et al. 2007). Results obtained also indicate a negative genetic correlation between LWW and LG. The high correlation between LWW and $\operatorname{MOE}_{\text {Rad }}(0.48)$ can explain the negative relation of $\mathrm{MOE}_{\mathrm{Rad}}$ and LG. These genetic correlations indicate that selecting trees with lower LG, for example for pulp production, will increase the radial modulus of elasticity of the wood.

Table 4 presents the expected correlated responses for several traits, including growth traits, selecting for LG, $\mathrm{MOE}_{\mathrm{Rad}}$ and $\mathrm{MOR}_{\mathrm{Rad}}$ with an intensity of $10 \%$.

Selection for low LG for pulp production for instance, will result in an increase in important traits such as RD, DBH and $\operatorname{MOE}(22 \%, 1 \%$ and $22 \%$ respectively), due to the negative correlations. Reduction in lignin content would be also advantageous by decreasing energy needs and chemical consumption.

Improvement of $\mathrm{MOE}_{\mathrm{Rad}}$ by selection would result in an overall improvement due to the positive correlation found with the other traits. Almost the same result could be obtained by selecting $M_{\text {Rad }}$ except for LWD and growth traits where it is expected a have a low impact (Tables 3 and 4).

\section{Conclusions}

Results of this study showed that lignin amount is under a moderate genetic control, but due to the low CV observed, selection for low lignin content through breeding could yield modest gains. Selection based on density will result in a decrease of LG, and that lignin content is more dependent on the proportion of latewood. Additionally, the presented heritability results, based on a non-destructive method, using sample cores, indicate that $\mathrm{MOE}_{\mathrm{Rad}}$ and $\mathrm{MOR}_{\mathrm{Rad}}$ are under a moderate genetic control, and the differences between families with the highest and the lowest $\mathrm{MOR}_{\mathrm{Rad}}$ and $\mathrm{MOE}_{\mathrm{Rad}}$ indicate that selection for higher resistance and elasticity through breeding could yield some genetic gains. Positive correlations observed between both mechanical traits and RD indicate that selecting for RD will not result in a decrease of $M O R_{\mathrm{Rad}}$, and that it is possible to obtain an increase in $\mathrm{MOE}_{\mathrm{Rad}}$. The high genetic correlations observed between the $\mathrm{MOE}_{\mathrm{Rad}}$ and latewood components make it a strong trait for indirect genetic improvement. Results suggest that $\mathrm{MOR}_{\mathrm{Rad}}$ could be improved through the enhancement of earlywood density, even though this trait is less affected by intra-ring variations than $\mathrm{MOE}_{\text {rad}}$.

Based on these results, it seems possible for breeders to adjust the course of selection depending on the type of end product. For pulp production, the improvement of density with a reduction of lignin is desirable, so the increase of LWP would be the most suitable way to obtain higher wood density. Tree improvement programs should decide which traits will be of most importance in the future before incorporating them into their breeding programs.

\section{References}

AACC-Standards (2001) Method 28-21A: X-ray examination for internal insect infestation; $28-22 \mathrm{~A}$ cracking-flotation test for internal insects in whole grains

Alves A, Schwanninger M, Pereira H, Rodrigues J (2006) Analytical pyrolysis as a direct method to determine the lignin content in wood - Part 1: comparison of pyrolysis lignin with Klason lignin. J Anal Appl Pyrol 76:209-213

Baltunis BS, Wu HX, Powell MB (2007) Inheritance of density, microfibril angle, and modulus of elasticity in juvenile wood of Pinus radiata at two locations in Australia. Can J For Res $37: 2164-2174$

Bodig J (1965) The effect of anatomy on the initial stress-strain relationship in transverse compression. Forest Prod J 15(5):197-202

Bodig J (1981) Mechanics of wood and wood composites. Van Nostrand Reinhold Company, New York

Brancheriau L, Bailleres H, Guitard D (2002) Comparison between modulus of elasticity values calculated using 3 and 4 point bending tests on wooden samples. Wood Sci Technol 36:367-383

Chantre G, Rozenberg P, Baonza V, Macchioni N, Le Turcq A, Rueff M, Petit-Conil M, Heois B (2002) Genetic selection within Douglas fir (Pseudotsuga menziesii) in Europe for papermaking uses. Ann For Sci 59:583-593

Falconer DS, Mackay TFC (1996) Introduction to quantitative genetics. Springer, New York

Fujimoto T, Akutsu H, Nei M, Kita K, Kuromaru M, Oda K (2006) Genetic variation in wood stiffness and strength properties of hybrid larch (Larix gmelinii var. japonica x L kaempferi). J For Res 11:343-349

Gaspar MJ, Louzada JL, Aguiar A, Almeida MH (2008a) Genetic correlations between wood quality traits of Pinus pinaster Ait. Ann For Sci 65:703

Gaspar MJ, Louzada JL, Silva ME, Aguiar A, Almeida MH (2008b) Age trends in genetic parameters of wood density components in 46 half-sibling families of Pinus pinaster. Can J For Res $38: 1470-1477$

Gaspar MJ, De-Lucas A, Alia R, Paiva JAP, Hidalgo E, Louzada J, Almeida H, Gonzalez-Martinez SC (2009) Use of molecular 
markers for estimating breeding parameters: a case study in a Pinus pinaster Ait. progeny trial. Tree Gen Genom 5:609-616

Gilmour A, Gogel B, Cullis B, Welham S, Thompson R (1998) ASREML Users Manual. VSN International, NSW Agriculture, Orange, Australia

Greaves BL, Schimleck LR, Borralho NMG, Michell AJ, Raymond CA (1996) Genetic control and repeatability of near infrared reflectance from Eucalyptus nitens woodmeal. Appita J 49:423-426

Hannrup B, Cahalan C, Chantre G, Grabner M, Karlsson B, Le Bayon I, Jones GL, Muller U, Pereira H, Rodrigues JC, Rosner S, Rozenberg P, Wilhelmsson L, Wimmer R (2004) Genetic parameters of growth and wood quality traits in Picea abies. Scand J For Res 19:14-29

Harris JM (1989) Spiral grain and wave phenomena in wood formation. Springer, Berlin Heidelberg New York

Ilic J (1995) Advantages of prefreezing for reducing shrinkage-related degrade in eucalypts: general considerations and review of the literature. Wood Sci Technol 29:277-285

Jozsa L, Richards J, Johnson S (1987) Calibration of Forintek's directreading densitometer. CFS Contract Report No. 55-12-001. Forintek Canada Corp, Vancouver

Kennedy RW (1967) Wood in transverse compression: influence of some anatomical variables and density on behaviour. Forest Prod J 18(3):36-40

Kumar S, Dungey HS, Matheson AC (2006) Genetic parameters and strategies for genetic improvement of stiffness in Radiata pine. Silvae Genet 55:77-84

Liu JY, Ross RJ (2005) Relationship between radial compressive modulus of elasticity and shear modulus of wood. Wood Fiber Sci 37:201-206

Louzada JLPC (2000) Variação fenotípica e genética em características estruturais na madeira de Pinus pinaster Ait. Departamento Florestal, Universidade de Trás-os-Montes e Alto Douro, Vila Real, p 293

Louzada JLPC, Fonseca FMA (2002) The heritability of wood density components in Pinus pinaster Ait. and implications for tree breeding. Ann For Sci 59:867-873

Machado JS, Cruz HP (2005) Within stem variation of Maritime Pine timber mechanical properties. Holz Roh Werkst 63:154-159

Madsen B (1992) Structural behaviour of timber. Timber Engineering Ltd., Canada

Matheson AC, Gapare WJ, Ilic J, Wu HX (2008) Inheritance and genetic gain in wood stiffness in radiata pine assessed acoustically in young standing trees. Silvae Genet 57:56-64

Ohbayashi H, Booker RE, Ball RD, Ridoutt BG (2001) Radial modulus of rupture in radiata pine measured by individual rings. J Wood Sci 47:233-236

Perez DS, Guillemain A, Chantre G, Alazard P, Alves A, Rodrigues J, Rozenberg P, Plomion C, Robin E (1995) Improvement of wood, pulp and paper quallity of maritime pine (Pinus pinaster Ait. ) by combining rapid assessment techniques and genetics, 13th International Symposium on Wood, Fibres and Pulping Chemistry, Oakland, New Zealand, pp 101-108

Perez DD, Guillemain A, Alazard P, Plomion C, Rozenberg P, Rodrigues JC, Alves A, Chantre G (2007) Improvement of Pinus pinaster Ait. elite trees selection by combining near infrared spectroscopy and genetic tools. Holzforschung 61:611-622

Perry D, Hopkins E (1967) Importation of breeding material of Pinus pinaster Ait. from Portugal. For Dep W A Bulletin 75

Polge H (1978) Fifteen years of wood radiation densitometry. Wood Sci Technol 12:187-196

Pot D, Chantre G, Rozenberg P, Rodrigues JC, Jones GL, Pereira H, Hannrup B, Cahalan C, Plomion C (2002) Genetic control of pulp and timber properties in maritime pine (Pinus pinaster Ait.). Ann For Sci 59:563-575

Pot D, Rodrigues JC, Rozenberg P, Chantre G, Tibbits WN, Cahalan C, Pichavant F, Plomion C (2006) QTLs and candidate genes for wood properties in maritime pine (Pinus pinaster Ait). Tree Gen Genom 2:10-24

Raymond CA, Schimleck LR (2002) Development of near infrared reflectance analysis calibrations for estimating genetic parameters for cellulose content in Eucalyptus globulus. Can J For Res 32:170-176

Santos JA, Pinho ACM (2004) New advances for the application of Eucalyptus as a structural wood. Silva Lusit 12:43-50

Schwanninger M, Hinterstoisser B (2002) Klason lignin: Modifications to improve the precision of the standardized determination. Holzforschung 56:161-166

Steffenrem A, Saranpaa P, Lundqvist SO, Skroppa T (2007) Variation in wood properties among five full-sib families of Norway spruce (Picea abies). Ann For Sci 64:799-806

Sykes R, Li BL, Isik F, Kadla J, Chang HM (2006) Genetic variation and genotype by environment interactions of juvenile wood chemical properties in Pinus taeda L. Ann For Sci 63:897-904

Tsoumis G (1991) Science and technology of wood: structure, properties, utilization. Chapman \& Hall, New York

Ukrainetz NK, Kang KY, Aitken SN, Stoehr M, Mansfield SD (2008) Heritability and phenotypic and genetic correlations of coastal Douglas fir (Pseudotsuga menziesii) wood quality traits. Can J For Res 38:1536-1546

Xavier J, Avril S, Pierron F, Morais J (2007) Novel experimental approach for longitudinal-radial stiffness characterization of clear wood by a single test. Holzforschung 61:573-581

Zobel BJ, Talbert J (1984) Applied forest tree improvement. John Wiley \& Sons, New York

Zobel BJ, van Buijtenen JP (1989) Wood variation - its causes and control. Springer, Berlin 